Article

\title{
In Vivo Anti-Inflammation Potential of Aster koraiensis Extract for Dry Eye Syndrome by the Protection of Ocular Surface
}

\author{
Sung-Chul Hong ${ }^{1}$, Jung-Heun Ha ${ }^{2,3}{ }^{\circledR}$, Jennifer K. Lee ${ }^{4}$, Sang Hoon Jung ${ }^{5,6}$ and \\ Jin-Chul Kim ${ }^{1, *}$ \\ 1 Natural Informatics Research Center, Korea Institute of Science and Technology (KIST), Gangneung 25451, \\ Korea; schong@kist.re.kr \\ 2 Research Center for Industrialization of Natural Neutralization, Dankook University, Cheonan 31116, Korea; \\ ha@dankook.ac.kr \\ 3 Department of Food Science and Nutrition, Dankook University, Cheonan 31116, Korea \\ 4 Food Science \& Human Nutrition Department, University of Florida, Gainesville, FL 32611, USA; \\ leejennifer@ufl.edu \\ 5 Natural Product Research Center, Korea Institute of Science and Technology (KIST), Gangneung 25451, \\ Korea; shjung@kist.re.kr \\ 6 Division of Bio-Medical Science and Technology, KIST School, Korea University of Science and \\ Technology (UST), Daejeon 34113, Korea \\ * Correspondence: jckim@kist.re.kr; Tel.: +82-33-650-3515
}

Received: 23 September 2020; Accepted: 17 October 2020; Published: 23 October 2020

\begin{abstract}
Dry eye syndrome (DES) is a corneal disease often characterized by an irritating, itching feeling in the eyes and light sensitivity. Inflammation and endoplasmic reticulum (ER) stress may play a crucial role in the pathogenesis of DES, although the underlying mechanism remains elusive. Aster koraiensis has been used traditionally as an edible herb in Korea. It has been reported to have wound-healing and inhibitory effects against insulin resistance and inflammation. Here, we examined the inhibitory effects of inflammation and ER stress by A. koraiensis extract (AKE) in animal model and human retinal pigmented epithelial (ARPE-19) cells. Oral administration of AKE mitigated DE symptoms, including reduced corneal epithelial thickness, increased the gap between lacrimal gland tissues in experimental animals and decreased tear production. It also inhibited inflammatory responses in the corneal epithelium and lacrimal gland. Consequently, the activation of NF- $\mathrm{kB}$ was attenuated by the suppression of cyclooxygenase- 1 (COX-1) and cyclooxygenase-2 (COX-2). Moreover, AKE treatment ameliorated TNF- $\alpha$-inducible ocular inflammation and thapsigargin (Tg)-inducible ER stress in animal model and human retinal pigmented epithelial (ARPE-19) cells. These results prove that AKE prevents detrimental functional and histological remodeling on the ocular surface and in the lacrimal gland through inhibition of inflammation and ER stress, suggesting its potential as functional food material for improvement of DES.
\end{abstract}

Keywords: functional food; dry eye; Aster koraiensis; animal model and human retinal pigmented epithelial (ARPE-19) cells

\section{Introduction}

Dry eye (DE) has been identified as a common disease of the eye, which is induced by the failure of tear production and tear retention in the ocular surface [1]. Dry eye syndrome (DES), also known as keratoconjunctivitis sicca, is primarily caused by genetic factors, autoimmunity, and external environmental insults. A previous cohort study estimated that approximately $14.5 \%$ of 
the US population suffers from DE [2]. DE is mainly caused by the increased osmolality of the tear film and immune response on the ocular surfaces [3]. When tears lose their integrity or excessively evaporate, the tear film becomes thinner and unstable [4]. The weakened tear film results in damage with increased inflammatory responses on ocular surfaces. The tear film is the primary defensive line of the eye against foreign pathogens and abiotic factors, and it also maintains ocular homeostasis $[5,6]$.

Furthermore, inflammation induced by an imbalance of ocular homeostasis triggers the recruitment of pro-inflammatory immune cells. Consequently, the lacrimal unit remodels its structures and the tear film properties [7-9]. Growing evidence suggests that DE-related ocular surface inflammation is mediated by immune cells [10]. Infiltrating inflammatory cells from peripheral circulatory blood were determined to secrete inflammatory cytokines such as interleukin (IL)-1, 6, 8, and 10 and tumor necrosis factor (TNF)- $\alpha$ on ocular surfaces. These cytokines degrade the corneal epithelial barrier and further induce apoptosis in the conjunctiva and lacrimal gland. Thus, an inflammatory response impedes the integrity of the ocular surfaces and accelerates the progression of DE [11-13].

The endoplasmic reticulum (ER) is a cellular organelle located in the cytoplasm. The ER has been known to metabolize proteins and lipids (biosynthesis, packaging, and secretion), and it stores calcium ions, which play a role as a cellular signal regulator. ER stress occurs by protein misfolding, including glycosylation or disulfide bond formation, protein overexpression, or mutations in protein $\mathrm{s}$ [14]. Severe intracellular $\mathrm{Ca}^{2+}$ dysregulations can promote cell death through apoptosis [15]. ER stress has received growing attention in many pathophysiological disorders, such as cardiovascular diseases, neurodegenerative diseases, inflammatory bowel disease, and rheumatoid arthritis [16]. Recently, it was suggested that ER stress is also related to DES [17].

Conventional therapeutic agents such as artificial tears, anti-inflammatory drugs, and corticosteroids have been determined to help DE patients in mitigating uncomfortable ocular symptoms and improving their clinical and pathological conditions for the short term [18-20]. However, this modality provides only temporary symptomatic relief, and up to two-thirds of DES sufferers complain of persisting symptoms despite such treatments [21]. Due to the limitations of medical treatment, a new therapeutic approach for DES is needed. An alternative method that can be presented is improvement through ingestion of functional food, which is a non-medical treatment method. Functional food derived from natural products was reported to have low side effects and to be safe for long-term intake [22-24]. In particular, it has preventive effects such as prevention of recurrence by improving the physical constitution during long-term ingestion [25]. In this study, Aster koraiensis extract (AKE) was selected as a candidate material of functional food to improve DES symptoms. A. koraiensis, also known as Korean starwort, is an herbaceous perennial plant of the Asteraceae family. Because A. koraiensis is widely distributed in most regions of Korea [26], it has been used as traditional herbal medicine and food item in the country $[27,28]$. A. koraiensis has been reported to inhibit diabetic inflammation $[29,30]$ and enhance wound healing on the skin and during bronchitis [31]. Moreover, chlorogenic acid and 3,5-di-O-caffeoylquinic acid, both isolated from A. koraiensis, have been used to relieve symptoms of diabetic-related diseases [32,33].

In this study, we produced an extract to examine the improving effect of $A$. koraiensis, a medical edible herb crop in Korea, on DE. The functionality of $A$. koraiensis extract was evaluated in an animal model in which scopolamine-induced DE. To investigate the detailed mechanism of action, we confirmed the possibility of improving DE in A. koraiensis via animal tissues and human retinal pigmented epithelial (ARPE-19) cells. In this way, we try to prove the value that $A$. koraiensis can be used as a functional food material.

\section{Materials and Methods}

\subsection{Plant Material and Preparation of A. koraiensis Extracts}

A. koraiensis was collected from Jeongseon-gun, Gangwon-do, Republic of Korea, in September 2016. The plant's aerial parts, including the flowers and leaves, were thoroughly washed with water 
to remove impurities and were further dried in the shade for 1 month. The medicinal plant mixture was extracted from the dried plants with ethanol $(\mathrm{EtOH})$ by maceration at room temperature for 3 days. A. koraiensis ethanol extracts (AKE) were combined and concentrated by evaporation in a rotary evaporator at $60-70{ }^{\circ} \mathrm{C}$. The EtOH extracts were then freeze-dried.

\subsection{Antioxidative Activities of AKE}

The antioxidative capacity of AKE related to either electron or radical scavenging was scrutinized with three different analytical methods and backgrounds; (1) A 1,1-diphenyl-2-picrylhydrazyl (DPPH), (2) the ferric reducing antioxidant power (FRAP), and the Trolox equivalent antioxidant capacity (TEAC). DPPH assay was performed to assess the stable DPPH radical generating capacity by AKE. FRAP assay was tested to understand reducing activity from ferric to ferrous iron by AKE. TEAC assay was intended to assess radical scavenging cation ABTS+ $\left(2,2^{\prime}\right.$-azinobis (3-ethylbenzothiazoline-6-sulfonic acid) by radical quenching or electron donation. Each evaluation was performed through the following experimental methods.

A 1,1-diphenyl-2-picrylhydrazyl (DPPH) assay was conducted as described by Serpen et al. [34] and Thaipong [35], with slight modifications. Briefly, $0.1 \mathrm{~mL}$ of $200 \mathrm{M}$ DPPH reagent (Sigma-Aldrich Co., St. Louis, MO, USA) was added to $0.1 \mathrm{~mL}$ of each sample in 96-well plates. After incubation in the dark for $30 \mathrm{~min}$, the absorbance was measured at $520 \mathrm{~nm}$ using a microplate reader (Spectramax M2E; Thermo Fisher Scientific, Waltham, MA, USA). Ascorbic acid (Sigma-Aldrich) as a DPPH-scavenging compound was used as a standard. Assay results were expressed in mg ascorbic acid/g.

The ferric reducing antioxidant power (FRAP) was assessed via the method developed by Benzie and Strain [36]; however, it had slight modifications. Briefly, acetic acid buffer (pH 3.6, 23 mM) was made by dissolving sodium acetate (Sigma-Aldrich) in acetic acid (Sigma-Aldrich). A $10 \mathrm{mM}$ solution of 2,4,6-tripyridyl-s-triazine (TPTZ) was made by mixing $40 \mathrm{mM} \mathrm{HCl}$ (Sigma-Aldrich) and TPTZ (Sigma-Aldrich). A total of $25 \mu \mathrm{L}$ of the AKE extract was then added to the FRAP reagent (acetic acid, $10 \mathrm{mM}$; TPTZ, $20 \mathrm{mM} ; \mathrm{FeCl}_{3} \cdot 6 \mathrm{H}_{2} \mathrm{O}=10: 1: 1$ ) and incubated in the dark at $37^{\circ} \mathrm{C}$ for $15 \mathrm{~min}$. The absorbance was measured at $593 \mathrm{~nm}$ using a microplate reader. $\mathrm{FeSO}_{4}$ (Sigma-Aldrich) was employed as a standard in this assay. Assay results were expressed in $\mathrm{nM} \mathrm{FeSO}_{4} / \mathrm{mL}$.

The Trolox equivalent antioxidant capacity (TEAC) was measured as described by Oki et al. [37] and Re et al. [38], with minor modifications. Briefly, $200 \mu \mathrm{L}$ of 2,2'-azino-bis (3-ethylbenzothiazoline -6-sulfonic acid; ABTS) reagent (Sigma-Aldrich) was added to $10 \mu \mathrm{L}$ of each sample in 96-well plates. After a 60-min incubation in the dark, the absorbance was measured at $405 \mathrm{~nm}$ using a microplate reader. The reaction rate was calibrated using Trolox equivalent (TE). Assay results were expressed in $\mathrm{g} \mathrm{TE} / \mathrm{mL}$.

\subsection{Total Polyphenol and Flavonoid Contents of AKE}

Total polyphenol content was measured using the method described by Alves et al. [39], with minor modifications. Briefly, $10 \mu \mathrm{L}$ of Folin-Denis reagent (Sigma-Aldrich) was added to $160 \mu \mathrm{L}$ of each sample in 96-well plates. After $8 \mathrm{~min}, 30 \mu \mathrm{L}$ of sodium carbonate (Showa Chemical Industry, Tokyo, Japan) was added to the mixture. After incubation in the dark for $2 \mathrm{~h}$, the absorbance was measured at $765 \mathrm{~nm}$ using the Spectramax M2E microplate reader. Gallic acid (Sigma-Aldrich) was also used as the standard curve to extrapolate gallic acid equivalent (GAE). Results were expressed in mg GAE/mL.

Total flavonoid content was analyzed using slight modifications of the methods previously described by Pourmorad et al. [40] and Marinova et al. [41]. In brief, $400 \mu \mathrm{L}$ of each sample was mixed with $1200 \mu \mathrm{L}$ of EtOH (Junsei Chemical Co., Tokyo, Japan) and $240 \mu \mathrm{L}$ of distilled water. Subsequently, $80 \mu \mathrm{L}$ of $10 \%$ aluminum nitrate (Sigma-Aldrich) was added, followed by $80 \mu \mathrm{L}$ of $1.0 \mathrm{M}$ potassium acetate (Sigma-Aldrich). The mixture was allowed to stand in the dark for $40 \mathrm{~min}$, and the absorbance was measured at $415 \mathrm{~nm}$ using the microplate reader. Quercetin (Sigma-Aldrich) was used to construct the standard curve against quercetin equivalents $(\mathrm{QE})$, and the assay results were expressed in $\mathrm{mg} \mathrm{QE} / \mathrm{mL}$. 


\subsection{Animal Experiment and Induction of DE Model}

All procedures received approval from the Institutional Animal Care and Use Committee (IACUC) of Korea Institute of Science and Technology (KIST): KIST No. 2020-002, Gangneung Institute, and they were performed according to the Association for Research in Vision and Ophthalmology (ARVO) statement for the Use of Animals in Ophthalmic and Vision Research. Mice were accommodated in the animal room with air conditioning, temperatures of $22 \pm 2{ }^{\circ} \mathrm{C}$, humidity of $50 \pm 10 \%$, and $12 \mathrm{~h}$ light $/ 12 \mathrm{~h}$ dark circadian cycles. Food and water were supplied ad libitum. Mice were acclimatized for 1 week and were later assigned into five groups composed of seven male 6-week-old BALB/c mice. Experimental DE in mice was achieved by twice-daily intraperitoneal (i.p.) injection of $200 \mu \mathrm{L}$ $(2.5 \mathrm{mg} / \mathrm{mL})$ of phosphate buffered saline (PBS)-diluted scopolamine (Sigma-Aldrich). Groups of mice were orally administered with AKE once per day at concentrations of 0 (as vehicle control), 10, 50, or $100 \mathrm{mg} / \mathrm{kg}$ in $200 \mu \mathrm{L} \mathrm{EtOH}$. In the control group, only PBS buffer was injected without scopolamine. In the case of AKE, $0 \mathrm{mg} / \mathrm{kg}$ in $200 \mu \mathrm{L}$ EtOH was administered when orally administered as in the DE group. After 2 weeks, tear production was quantified by a standard Schirmer's test strip placed in the lower one-third of the temporal eyelid before the eye was closed for $1 \mathrm{~min}$. After the strip was removed, the length of the wet point was measured in millimeters in order to determine the Schirmer's test value. For measurements of the tear breakup time (TBUT), $5 \mu \mathrm{L}$ of sodium fluorescein was instilled into the eye and photographed. Corneal surface staining was performed to assess the extent of corneal surface changes. The corneal surface was observed and scored after the administration of one drop of $3 \%$ fluorescein (Sigma-Aldrich, St. Louis, MO, USA) into the inferior lateral conjunctival sac. The staining of the cornea was evaluated in a blinded manner. Mice are euthanized through cervical dislocation. When removing the cornea, click the mouse's eyelid and use forceps to cut out the eyeball's optic nerve that pops out and removes the cornea. After removing the crystalline lens inside the cornea, store in a freezer at $-80^{\circ} \mathrm{C}$. After pulling the mouse's lower jaw with forceps for removal of the lacrimal gland, cut off the epidermis of the pulled part so that the lower part of the mouse's face can be seen. A lacrimal gland located near the lower jaw of the mouse can be secured. The secured lacrimal gland tissue is stored frozen at $-80^{\circ} \mathrm{C}$.

\subsection{Histology}

The corneal epidermal tissue and lacrimal gland tissues were collected, fixed in $10 \%$ formaldehyde, and processed for paraffin embedding and sectioning. Sections were stained with hematoxylin and eosin (H \& E) and examined a microscope (TE-2000U, Nikon, Tokyo, Japan) at X40. Central corneal epithelial thickness was evaluated in 5 sections for each cornea.

\subsection{Western Blot Analysis}

Total protein lysate was extracted from the corneal epidermal tissue and lacrimal glands of each mouse group and from APRE-19 cells after washing with ice-cold PBS (Invitrogen, Carlsbad, CA, USA) three times. Radioimmune precipitation assay (RIPA) buffer (Pierce, Rockford, IL, USA) was applied to the samples with protease inhibitors (Cell Signaling Technology, Danvers, MA, USA) and phosphatase inhibitor (PMSF, Thermo Fisher Scientific, Waltham, MA, USA) at $4{ }^{\circ} \mathrm{C}$. After lysis, the supernatant was collected after centrifugation at $12,000 \times \mathrm{g}$ for $15 \mathrm{~min}$ at $4{ }^{\circ} \mathrm{C}$. Protein lysates were loaded and separated using SDS-PAGE gels (Bio-RAD, Hercules, CA, USA) and transferred to polyvinylidene difluoride (PVDF) membranes (Bio-RAD) using a wet-transfer method at $4{ }^{\circ} \mathrm{C}$. Membranes were blocked with 5\% non-fat milk in tris-buffered saline and Tween-20 (TBS-T) for $1 \mathrm{~h}$ to prevent nonspecific binding. Blots were incubated with primary and secondary antibodies at room temperature, developed with chemiluminescence reagent (Pierce), and detected and analyzed using LAS-4000 (General Electric Image Quant LAS 4000 Biomolecular Imager; GE Healthcare, Chicago, IL, USA) in grayscale. Experimental protein band intensity on blots was normalized to the intensity of 
glyceraldehyde 3-phosphate dehydrogenase (GAPDH), which did not vary significantly by treatment. Primary and secondary antibodies are summarized in Table 1.

Table 1. Antibodies for western blot analysis.

\begin{tabular}{cccc}
\hline & Antibody & Dilution Factor & Corporation \\
\hline phospho-p65 & $1: 1000$ & Cell signaling \\
p65 & $1: 1000$ & Cell signaling \\
phospho-ERK & $1: 1000$ & Cell signaling \\
& ERK & $1: 1000$ & Santa Cruz \\
phospho-JNK & $1: 1000$ & Cell signaling \\
JNK & $1: 1000$ & Santa Cruz \\
phimary antibody & phpho-p38 & $1: 1000$ & Cell signaling \\
& ph8 & $1: 1000$ & Santa Cruz \\
& AMPKo-AMPK & $1: 1000$ & Cell signaling \\
& phospho-IKB & $1: 1000$ & Santa Cruz \\
& IKB & $1: 1000$ & Cell signaling \\
& COX-1 & $1: 1000$ & Santa Cruz \\
& COX-2 & $1: 1000$ & Cell signaling \\
& GAPDH & $1: 1000$ & Cell signaling \\
& Goat anti-mouse-HRP & $1: 2000$ & Cell signaling \\
\hline \multirow{2}{*}{ Gecondary antibody } & Goat anti-rabbit-HRP & $1: 5000$ & Thermo scientific \\
\hline
\end{tabular}

ERK, extracellular signal regulated kinase; JNK, c-Jun N-terminal kinase; AMPK, 5' adenosine monophosphate -activated protein kinase; IKB, inhibitor of nuclear factor kappa B; COX-1, cyclooxygenase-1; COX-2, cyclooxygenase-2; GAPDH, glyceraldehyde 3-phosphate dehydrogenase; HRP, horseradish peroxidase.

\subsection{Real-Time PCR (RT-qPCR)}

Total RNA was isolated from corneal epidermal tissue, lacrimal glands, and ARPE-19 cells with the RNase mini kit (Qiagen, Valencia, CA, USA). Genomic DNA was removed by digestion with DNase I (Qiagen). Reverse transcription was performed using $1 \mu \mathrm{g}$ of mRNA per sample with the RevertAid First Strand cDNA Synthesis Kit (Thermo Fisher Scientific, Waltham, MA, USA). Gene expression was assessed with a SYBR Green PCR mixture with gene-specific oligonucleotide primers using an AB 7500 real-time PCR machine (Thermo Fisher Scientific, Waltham, MA, USA). Primer sequences and parameters are described in Table 2. The expression of the target genes was normalized to the expression of $\beta$-Actin and glyceraldehyde 3-phosphate dehydrogenase (GAPDH), which was not significantly altered by treatments.

Table 2. RT-qPCR primer sequences ( $5^{\prime}$ to $\left.3^{\prime}\right)$.

\begin{tabular}{cccc}
\hline Transcript & Forward Primer & Reverse Primer & $\begin{array}{c}\text { Annealing Temp. } \\
\left({ }^{\circ} \mathbf{C}\right)\end{array}$ \\
\hline IL- $\beta$ & TCATTGTGGCTGTGGAGAAG & GGTGTGCCGTCTTTCATTAC & 53.8 \\
TNF- $\alpha$ & CTCAGATCATCTTCTCAA & CAGAGCAATGACTCCAAA & 55.1 \\
TGF- $\beta$ & GAAAGCCCTGTATTCCGTCTCCTT & CAACAATTCCTGGCGTTACCTTGG & 53.8 \\
IFN- $\gamma$ & AGCGGCTGACTGAACTCAGATTGTA GTCACAGTTTTCAGCTGTATAGGG & 61.2 \\
IL-6 & TTCCCTACTTCACAAGTC & GGTTTGCCGAGTAGATCT & 52.9 \\
IL-23 & CAAGCAGAACTGGCTGTTGTC & GCACCAGCGGGACATATGAA & 60.2 \\
MMP- 9 & CACAACCGACGACGACGAGTTGTG & CTGTGGTGAGGCCGAATAG & 65.0 \\
$\beta-A c t i n$ & TTGTTACCAACTGGGACGACATGG & GATCTTGATCTTCATGGTGCTAGG & 59.2 \\
GAPDH & ATGGTGAAGGTCGGTGTG & ACCAGTGGATGCAGGGAT- & 58.0 \\
\hline
\end{tabular}

IL-1 $\beta$, interleukin 1 beta; TNF- $\alpha$, Tumor necrosis factor alpha; TGF- $\beta$, Transforming growth factor beta; IFN- $\gamma$, Interferon gamma; IL-6, interleukin 6; IL-23, interleukin 23; MMP-9, Matrix metallopeptidase 9. 


\subsection{ARPE-19 Cell Culture}

Human retinal epithelial ARPE-19 cells (American Type Culture Collection, ATCC) were cultured in DMEM/F-12 media (Gibco, Carlsbad, CA, USA) containing 10\% FBS (HyClone Laboratories, Logan, UT, USA) and 1\% penicillin/streptomycin (HyClone Laboratories). To induce an inflammatory and endoplasmic response in ARPE-19 cells, $2 \times 10^{5}$ cells per well were cultured in 6 well plates. After culturing for $24 \mathrm{~h}, 200 \mu \mathrm{L}$ media solution with $10 \mu \mathrm{g} / \mathrm{mL}$ of TNF- $\alpha$ or $5 \mu \mathrm{mol} / \mathrm{L}$ thapsigargin $(\mathrm{Tg})$ was applied to the cells in the presence or absence of AKE $(0,0.1,1$, and $10 \mu \mathrm{g} / \mathrm{mL})$ for $12 \mathrm{~h}$. In the Control group case, the experiment was conducted with doubles without any inflammation-inducing factors or AKE.

\subsection{Intracellular Calcium Release}

Intracellular calcium $\left[\mathrm{Ca}^{2+}\right]_{\mathrm{i}}$ level was measured using a Fluo-4 NW calcium assay kit (F36206; Thermo Fisher Scientific, Waltham, MA, USA), according to the manufacturer's protocol. Briefly, $1 \times 10^{5}$ ARPE-19 cells per well were cultured in 96 well plates for $24 \mathrm{~h}$, and ER stress was induced by the treatment with $\operatorname{Tg}$ and AKE $(0,0.1,1$, and $10 \mu \mathrm{g} / \mathrm{mL})$ for $12 \mathrm{~h}$. Cells were then incubated with a cell-permeable calcium indicator (Flow $4 \mathrm{~A}$ ) for $1 \mathrm{hr}$ before treatment of $\mathrm{Tg}$ (final concentration, $5 \mu \mathrm{mol} / \mathrm{L})$. The $\left[\mathrm{Ca}^{2+}\right]_{\mathrm{i}}$ levels were accessed by measuring the fluorescent intensity using a microplate spectrophotometer (Bio-Tek Power Wave XS, Winooski, VT, USA). Image software (Bio-Tek software, Gen5) was applied for the subsequent quantitative analysis.

\subsection{VEGF- $\alpha$ Secretion}

$1 \times 10^{5}$ ARPE-19 cells per well were cultured in 96 well plates for $24 \mathrm{~h}$. In order to measure the vascular endothelial growth factor (VEGF)- $\alpha$ secretion, Tg with AKE $(0,0.1,1$, or $10 \mu \mathrm{g} / \mathrm{mL}$ ) were dissolved in the medium and treated with $100 \mu \mathrm{L}$ each, incubated for $24 \mathrm{~h}$, and then doubled and collected. VEGF- $\alpha$ protein secretion in the media was quantified using a commercial ELISA kit (BMS277-2; Invitrogen) as per the manufacturer's instructions using a microplate spectrophotometer (Bio-Tek Power Wave XS, Winooski, VT, USA).

\subsection{Statistical Analysis}

Results are presented as means \pm standard deviation (SD). Data were analyzed statistically using one-way ANOVA with Tukey's post hoc analysis. For $\left[\mathrm{Ca}^{2+}\right]_{i}$ determination, two-way ANOVA with Tukey's post hoc test was used. Data were analyzed using a two-factor ANOVA test. If analytical results showed significant time $X$ treatment interactions $(p<0.05)$, Tukey's post hoc multiple comparisons test was applied. $p<0.05$ was defined as statistically significant and was further indicated by a filled asterisk or number sign. All statistical analyses were performed using the GraphPad Prism 8 (San Diego, CA, USA).

\section{Results}

\subsection{Antioxidative Effects and Polyphenol and Flavonoid Contents of AKE}

Plants that are rich in secondary metabolites, including phenolics and flavonoids, have been identified to possess antioxidant properties afforded by their chemical structures and redox potentials [42]. As antioxidant activity is multifactorial and associated with several mechanisms [43], we performed three complementary tests to measure the antioxidant activity of AKE's DPPH radical scavenging activity, ferric reducing antioxidant power (FRAP), and Trolox equivalent antioxidant capacity (TEAC). The AKE was prepared at different concentrations: 0.1, 0.5, 1, 5, and $10 \mathrm{mg} / \mathrm{mL}$. As shown in Table 3, the DPPH radical scavenging activity of AKE at concentrations of 10, 5, and $1 \mathrm{mg} / \mathrm{mL}$ was determined to be significantly higher than at concentrations of 0.5 and $0.1 \mathrm{mg} / \mathrm{mL}$ $(10 \fallingdotseq 5 \fallingdotseq 1 \mathrm{mg} / \mathrm{mL}>0.5 \fallingdotseq 0.1 \mathrm{mg} / \mathrm{mL})$. FRAP and TEAC were increased as the concentration of AKE 
increased in a dose-dependent manner. The total polyphenol content increased dose-dependently as the concentration of AKE increased (Table 4). The total flavonoid content increased as the concentration increased in the following order: $10 \mathrm{mg} / \mathrm{mL}>5 \mathrm{mg} / \mathrm{mL}>1 \fallingdotseq 0.5 \fallingdotseq 0.1 \mathrm{mg} / \mathrm{mL}$ ). Thus, the amount of polyphenol and flavonoid is correlated with the antioxidant capacities. Moreover, the antioxidant activity is associated with a high concentration of extracts.

Table 3. DPPH radical scavenging activity, FRAP, and TEAC of $A$. koraiensis ethanol extracts (AKE).

\begin{tabular}{|c|c|c|c|c|c|}
\hline & $0.1 \mathrm{mg} / \mathrm{mL}$ & $0.5 \mathrm{mg} / \mathrm{mL}$ & $1 \mathrm{mg} / \mathrm{mL}$ & $5 \mathrm{mg} / \mathrm{mL}$ & $10 \mathrm{mg} / \mathrm{mL}$ \\
\hline $\begin{array}{c}\text { DPPH radical } \\
\text { scavenging activity } \\
\text { (mg ascorbic acid/g) }\end{array}$ & $30.8 \pm 2.55^{b}$ & $80.0 \pm 3.05^{b}$ & $112.7 \pm 3.02^{\mathrm{a}}$ & $117.8 \pm 0.58^{a}$ & $118.4 \pm 0.55^{\mathrm{a}}$ \\
\hline $\begin{array}{c}\text { FRAP } \\
\left(\mathrm{nM} \mathrm{FeSO}_{4} / \mathrm{mL}\right)\end{array}$ & $0.2 \pm 0.01^{\mathrm{e}}$ & $1.0 \pm 0.02^{\mathrm{d}}$ & $2.0 \pm 0.10^{c}$ & $7.8 \pm 0.41^{b}$ & $9.7 \pm 0.07^{\mathrm{a}}$ \\
\hline $\begin{array}{c}\text { TEAC } \\
(\mathrm{g} \mathrm{TE} / \mathrm{mL})\end{array}$ & $0.2 \pm 0.01^{\mathrm{e}}$ & $0.4 \pm 0.02^{d}$ & $0.9 \pm 0.10^{c}$ & $2.7 \pm 0.77^{b}$ & $2.9 \pm 0.01^{\mathrm{a}}$ \\
\hline
\end{tabular}

AKE, A. koraiensis ethanol extracts; DPPH, 2,2-diphenyl-1-picrylhydrazyl; FRAP, ferric reducing antioxidant power; TEAC, Trolox equivalent antioxidant capacity; TE, Trolox equivalent. Values are means $\pm S D, n=4$. Data were analyzed by one-way ANOVA analysis followed by Tukey's posthoc test. Means labeled without a common letter differ, $p<0.001$ (DPPH radical scavenging activity) and $p<0.01$ (FRAP and TEAC).

Table 4. Total polyphenol and flavonoid contents of $A$. koraiensis ethanol extracts (AKE).

\begin{tabular}{|c|c|c|c|c|c|}
\hline & $0.1 \mathrm{mg} / \mathrm{mL}$ & $0.5 \mathrm{mg} / \mathrm{mL}$ & $1 \mathrm{mg} / \mathrm{mL}$ & $5 \mathrm{mg} / \mathrm{mL}$ & $10 \mathrm{mg} / \mathrm{mL}$ \\
\hline $\begin{array}{l}\text { Total polyphenol content } \\
\text { (mg GAE } / \mathrm{mL})\end{array}$ & $0.2 \pm 0.00^{\mathrm{e}}$ & $0.6 \pm 0.01^{\mathrm{d}}$ & $0.9 \pm 0.01^{c}$ & $1.2 \pm 0.01^{b}$ & $2.6 \pm 0.03^{a}$ \\
\hline $\begin{array}{l}\text { Total flavonoids content } \\
(\mathrm{mg} \mathrm{QE} / \mathrm{mL})\end{array}$ & $2.2 \pm 0.58^{c}$ & $5.8 \pm 1.37^{c}$ & $15.5 \pm 0.61^{\mathrm{c}}$ & $32.7 \pm 1.51^{b}$ & $336.9 \pm 11.06^{\mathrm{a}}$ \\
\hline
\end{tabular}

$\mathrm{AKE}, A$. koraiensis ethanol extracts; GAE, 2 gallic acid equivalent; $\mathrm{QE}$, quercetin equivalents; Values are means $\pm \mathrm{SD}$, $\mathrm{n}=4$. Data were analyzed by one-way ANOVA analysis followed by Tukey's post hoc test. Means labeled without a common letter differ, $p<0.01$ (polyphenol and flavonoid).

\subsection{Effects of Aster koraiensis Ethanol Extracts on Eye Damage and Tear Production}

In the scopolamine-induced mouse model of DE, scopolamine was observed to trigger the breakup of tear film, decrease tear production, irritate the lacrimal gland, and shrink the corneal epithelial cells [5]. To identify the effect of the AKE on DE, we administered AKE $(0,10,50$, or $100 \mathrm{mg} / \mathrm{kg})$ orally once per day for 14 days to groups of mice with experimental DE. Eyes were stained with fluorescein in order to observe eye injury quantitatively. Under blue light, a green dot indicated the level of cornea damage (Figure 1A, black arrows). Quantitative analysis showed that AKE moderately ameliorated corneal damage in the DE mice in a dose-dependent manner (Figure 1B). The typical symptoms of DE include the quick dissipation of the tear film and a reduced amount of tear production [44]. To examine the mechanism by which AKE treatment inhibits corneal damage, tear breakup time (TBUT) and tear volume were observed. In DE mice, TBUT was reduced significantly, and AKE treatment at $100 \mathrm{mg} / \mathrm{kg}$ presented a reverse TBUT (Figure 1C). Additionally, the average volume of tear secretion was quantified using Schirmer's test. AKE treatment moderately enhanced tear production in a dose-dependent manner (Figure 1D). Taken together, these data show that AKE inhibited scopolamine-inducible corneal damage with increases in tear production and tear film stability. 


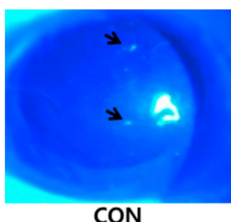

$\operatorname{CON}$
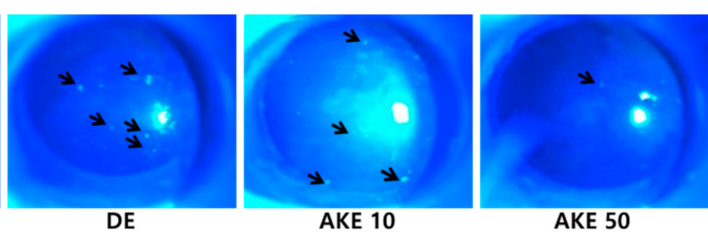

AKE 50

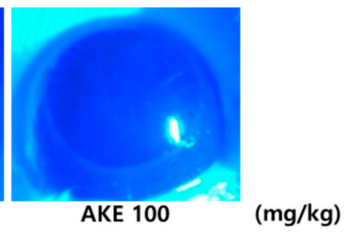

Scopolamine injection

(A)

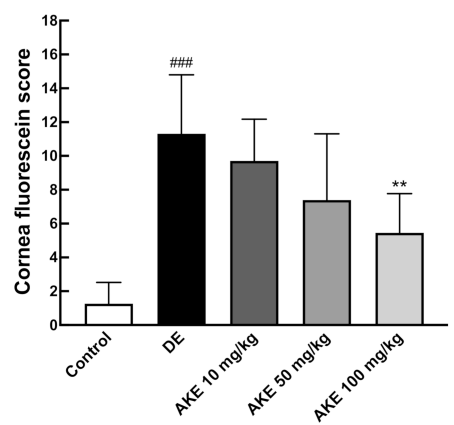

(B)

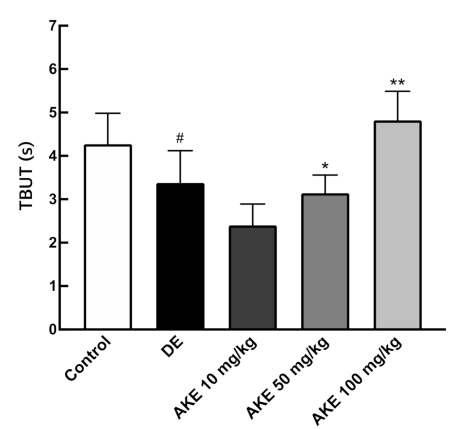

(C)

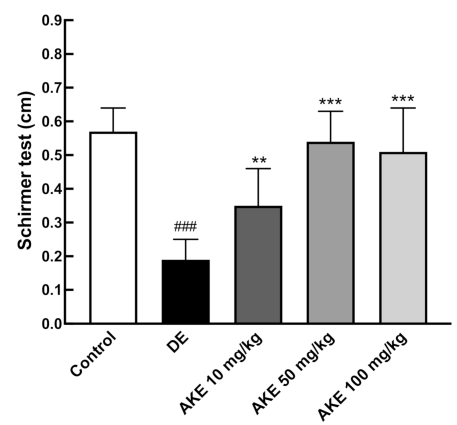

(D)

Figure 1. Effects of $A$. koraiensis ethanol extracts (AKE) on eye damage and tear production. Dry eye (DE) was reportedly induced by scopolamine injection, and AKE was administered at 0 (control; CON which was not induced by scopolamine injection, DE), 10 (AKE 10), 50 (AKE 50), or 100 mg/kg (AKE 100). (A) Representative images of corneal fluorescein staining. Black arrow indicates ocular damage spots of corneal fluorescein staining. (B) Quantitative analysis of images in A. (C) Tear breakup time (TBUT) was measured in seconds and analyzed. (D) Tear volume was measured using Schirmer's test. In the graph, each bar represents mean $\pm \mathrm{SD}$ of $\mathrm{n}=7$ mice per group. ${ }^{\#} p<0.05,{ }^{\# \# \#} p<0.001$ versus CON; ${ }^{*} p<0.05,{ }^{* *} p<0.01,{ }^{* * *} p<0.001$ versus DE. Data were analyzed statistically using one-way ANOVA followed by Tukey's post hoc test.

3.3. Histological Alterations of the Corneal Epithelial and Lacrimal Glands Following AKE Treatment in the DE Mouse Model

When DE symptoms develop, the corneal epithelial tissue thins to a delicate slim stratum [45]. In order to evaluate the effect of AKE on corneal epithelium from DE mice, we measured the thickness of corneal epithelial cells by histology. In Figure 2A, the dark pink area represents the corneal epithelial layer. This was significantly reduced in the DE group compared with the control (CON) group. AKE treatment inhibited the thinning of the corneal epithelial layer at doses of 50 and $100 \mathrm{mg} / \mathrm{kg}$ (Figure 2A,B).

Damage to the lacrimal glands is another general symptom of DE [46,47]. Lacrimal gland histopathology during AKE treatment of DE mice revealed a decrease in the number of infiltrating immune cells in the tissue, compared with the DE mice without AKE treatment (Figure 3C). Additionally, gaps in the glands were narrowed by the administration of AKE (Figure 3C). These results suggest that AKE is beneficial to corneal epithelial cells and lacrimal glands weakened during DE. Because these immune infiltrates are found to be common during $\mathrm{DE}$, we next elucidated immune regulation by AKE treatment in experimental DE. 


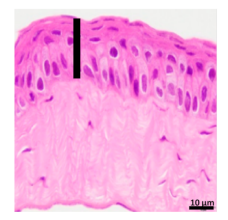

CON

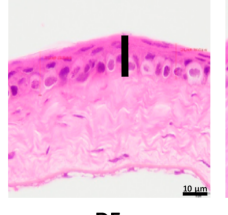

DE

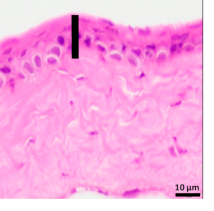

AKE 10

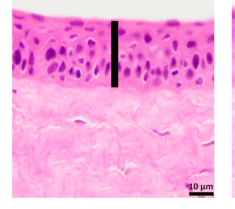

AKE 50

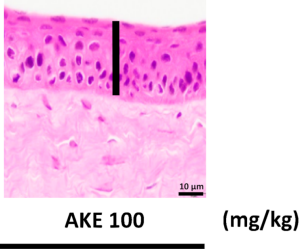

$\mathrm{mg} / \mathrm{kg})$

(A)

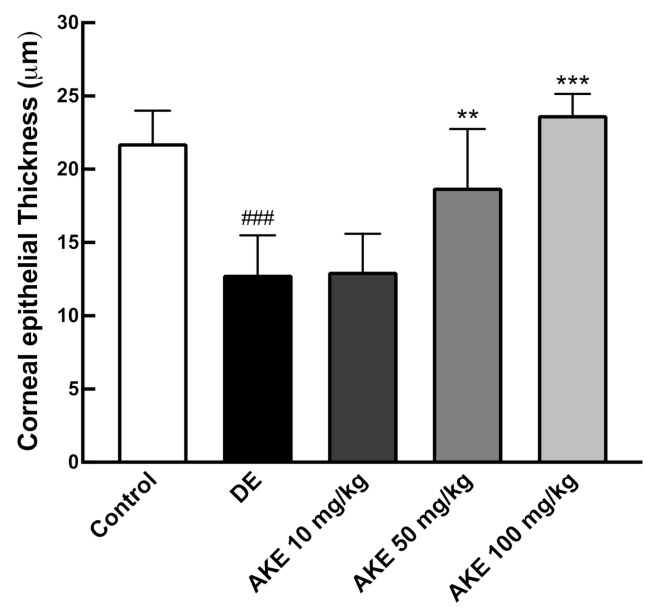

(B)
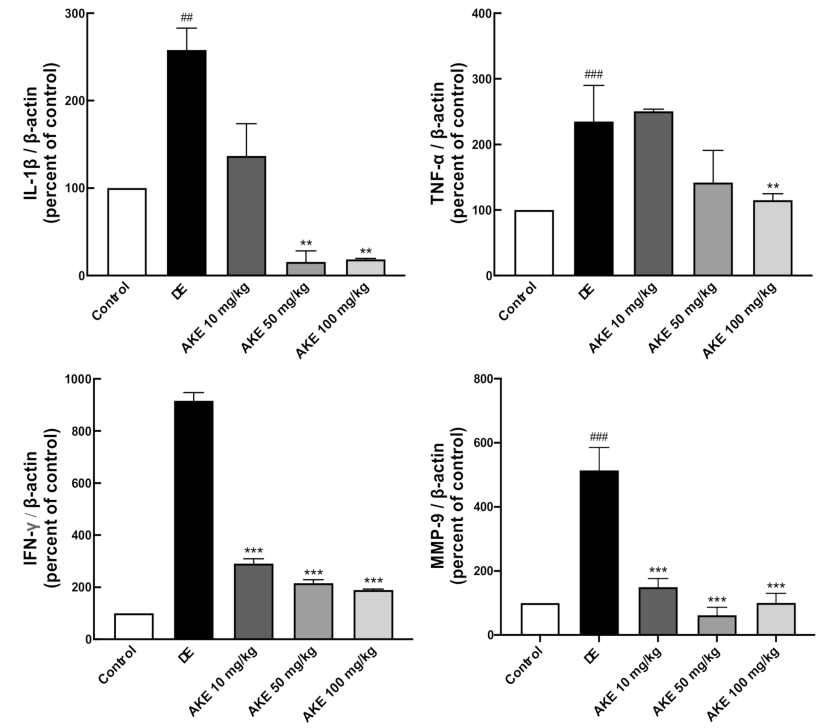

(C)

Figure 2. Effects of A. koraiensis ethanol extracts (AKE) on the corneal epithelial thickness and inflammatory cytokine expression. Dry eye (DE) was reportedly induced by scopolamine injection, and AKE was administered at 0 (control; CON which was not induced by scopolamine injection, DE), 10 (AKE 10), 50 (AKE 50), or $100 \mathrm{mg} / \mathrm{kg}$ (AKE 100). (A) Representative H and E staining images of histological sections of corneas. (B) Quantitative analysis of A. (C) Expression of inflammatory cytokines was accessed by real-time PCR (RT-qPCR) for each target gene (IL- $1 \beta$, TNF- $\alpha$, IFN- $\gamma$, and MMP-9). $\beta$-actin was used as an internal control. Each bar represents the mean \pm SD of $n=7$ mice per group. ${ }^{\# \#} p<0.01,{ }^{\# \#} p<0.001$ versus $\mathrm{CON} ;{ }^{* *} p<0.01,{ }^{* * *} p<0.001$ versus DE. Data were analyzed statistically using one-way ANOVA followed by Tukey's post hoc test. IL-1 $\beta$, interleukin 1 beta; TNF- $\alpha$, Tumor necrosis factor alpha; IFN- $\gamma$, Interferon gamma; MMP-9, Matrix metallopeptidase 9. 

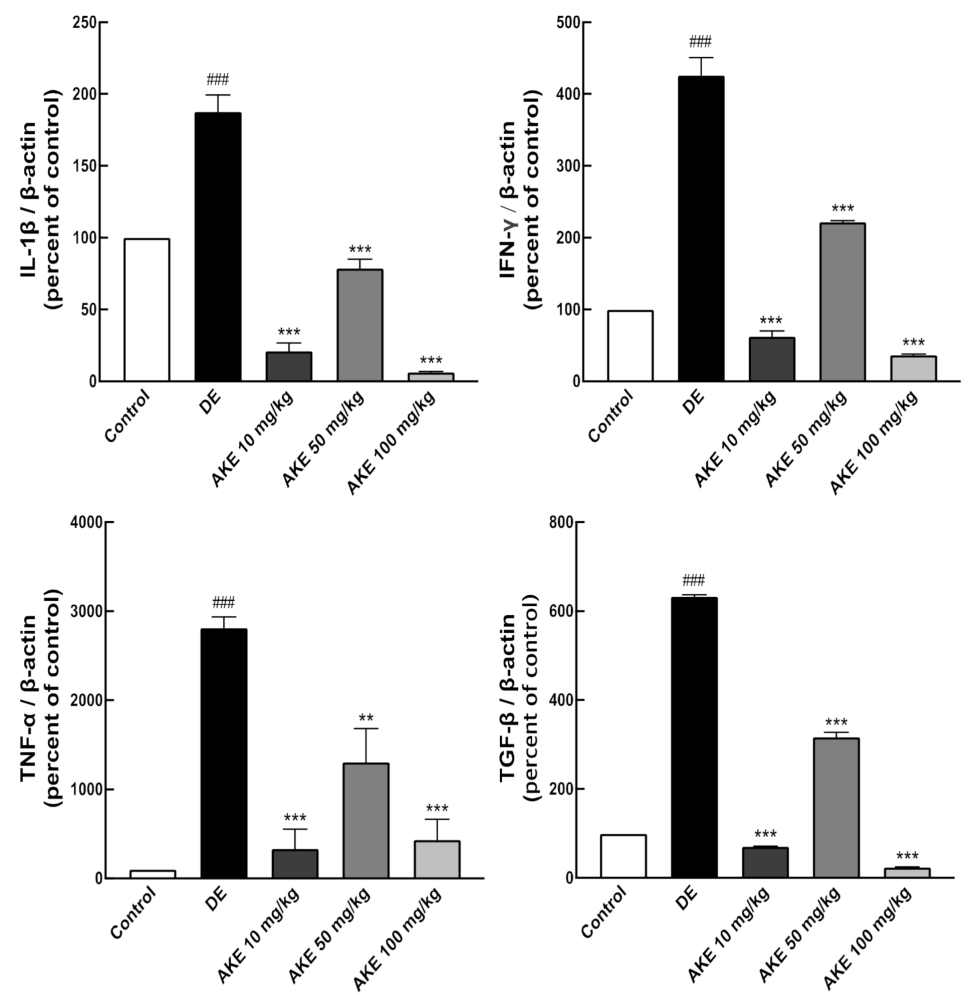

(A)
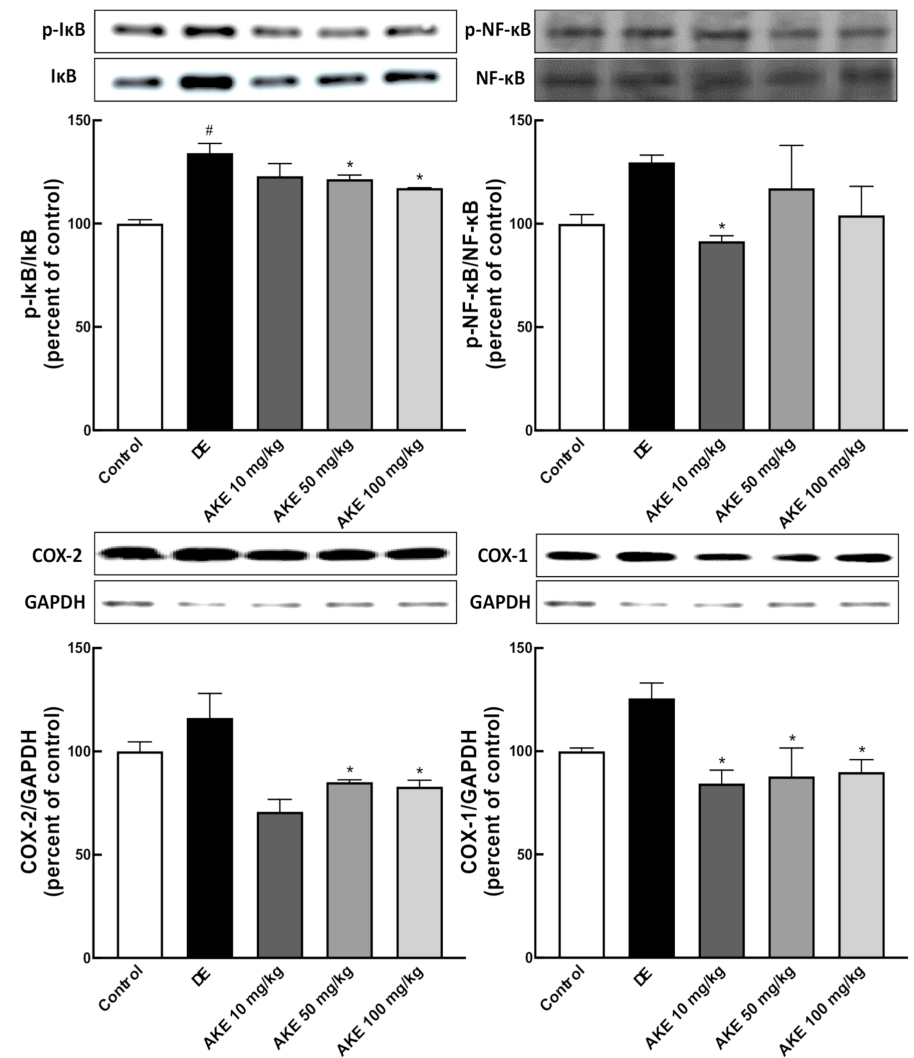

(B)

Figure 3. Cont. 


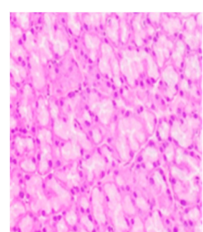

CON

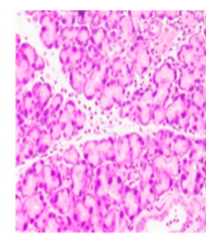

DE

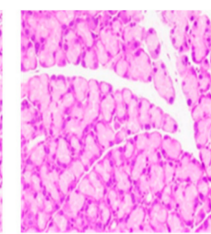

AKE 10

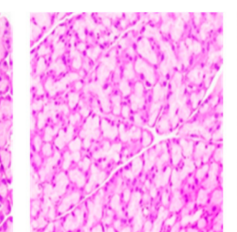

AKE 50

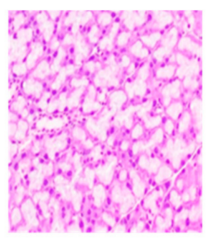

AKE 100 $(\mathrm{mg} / \mathrm{kg})$

(C)

Figure 3. Effects of A. koraiensis ethanol extracts (AKE) on the inflammatory response and gap between tissues in the lacrimal gland. Dry eye (DE) was reportedly induced by scopolamine injection, and AKE was administered at 0 (control; CON which was not induced by scopolamine injection, DE), 10 (AKE 10), 50 (AKE 50), or $100 \mathrm{mg} / \mathrm{kg}$ (AKE 100). (A) Expression of inflammatory cytokines was accessed using RT-qPCR for each target gene (IL- $1 \beta$, TNF- $\alpha$, IFN- $\gamma$, and Transforming growth factor beta (TGF- $\beta$ )). $\beta$-Actin was used as an internal control. (B) Inflammatory proteins were analyzed by western blot (WB). (Upper panels) Representative figures of WB for phosphorylated inhibitor of nuclear factor kappa $B$ (IkB) and total IkB, phosphorylated nuclear factor kappa B (NF-kB), and total NF-kB were targeted. Quantitative analysis revealed the ratio of phosphorylated protein/total protein. (Lower panels) The representative figures and their analyses of WB for cyclooxygenase (COX)-1 and COX-2. GAPDH was used for the loading control. (C) Representative H \& E-stained histological sections of lacrimal glands. The white area in the image shows the gaps between tissues in the lacrimal gland. Each bar represents the mean \pm SD of $\mathrm{n}=7$ mice per group. ${ }^{\#} p<0.05,{ }^{\# \# \#} p<0.001$ versus $\mathrm{CON}$; ${ }^{*} p<0.05,{ }^{* * *} p<0.001$ versus DE. Data were analyzed statistically using one-way ANOVA followed by Tukey's post hoc test.

\subsection{AKE Suppressed Immune Responses in the Corneal Epithelium and Lacrimal Glands of DE Model Mice}

Inflammatory responses are closely related to the integrity of the ocular surfaces and structure of ocular units $[7,13]$. To investigate the role of an immune response during the pathology of $\mathrm{DE}$, the relative mRNA expression levels of pro-inflammatory cytokines (interleukin 1 beta (IL-1 $\beta$ ), Tumor necrosis factor alpha (TNF- $\alpha$ ), Interferon gamma (IFN- $\gamma$ ), and Matrix metallopeptidase 9 (MMP-9)) were assessed in the corneal tissue and lacrimal gland from DE mice. All pro-inflammatory cytokines were found to be upregulated in the DE mice compared with the control mouse group. In the corneal tissues, AKE treatment inhibited the expression of each of these genes. In particular, IFN- $\gamma$ and MMP-9 were remarkably attenuated, even at a low dose $(10 \mathrm{mg} / \mathrm{kg})$ of AKE (Figure 2C, Figure 3A). In lacrimal glands, AKE suppressed the expression of inflammatory cytokines IL- $1 \beta$, TNF- $\alpha$, IFN- $\gamma$, and TGF- $\beta$ (Figure 3A). Especially, when $50 \mathrm{mg} / \mathrm{kg}$ of AKE was administered, cytokine expression did not decrease in proportion to the concentration in lacrimal gland tissues. However, AKE treatment experiment groups were found to reduce compared to the DE group that induced DE. Taken together, these data suggest that AKE treatment protected the eyes of the DE mice via effective anti-inflammatory activity in the corneal epithelium and lacrimal glands.

\subsection{AKE Inhibited Inflammatory Response in Lacrimal Gland}

To examine the molecular signaling pathway to be regulated by pro-inflammatory cytokines, the IkB/nuclear factor kappa B (NF-kB) axis, one of the main inflammations signaling pathways, was studied using western blot analysis of lacrimal gland tissue. Inactive NF- $\mathrm{K}$ w was observed to

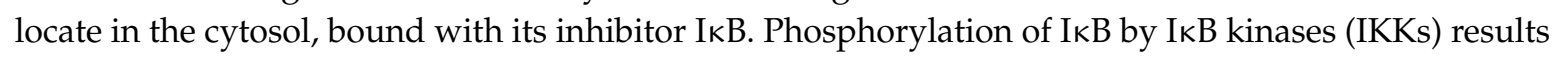
in the degradation of $\mathrm{I} \kappa \mathrm{B}$. Subsequently, NF- $\kappa \mathrm{B}$ translocates to the nucleus, where it regulates gene expression concerning inflammation [48]. Optimal induction of the NF- $\kappa B$ target genes also requires the phosphorylation of NF- $\mathrm{B}$ B proteins, such as p65 [49]. AKE treatment has suppressed phosphorylation of $\mathrm{I} \kappa \mathrm{B}-\alpha$, implying a decrease in immune reaction. NF- $\kappa \mathrm{B}$ has also showed a similar trend to that of I $\mathrm{K} B-\alpha$, but no significant difference between the control group and the DE group (Figure $3 \mathrm{~B}$ ). The target 
genes of the I $\mathrm{KB} / \mathrm{NF}-\mathrm{kB}$ axis increased in DE mice and were inhibited by AKE treatment (Figure 3B). Therefore, the immune response in lacrimal glands was markedly attenuated by AKE consumption.

\subsection{AKE Inhibited Inflammatory Reaction and ER Stress on ARPE-19 Cells}

Ocular inflammation has been known to occur not only on the corneal surface and lacrimal gland area in DE, but it also causes retinal damage. Two well-studied retinal damage-induced diseases are uveitis and diabetic retinopathy (DR) [50,51]. Thus, we observed the effect of AKE on a retinal damage model. The ARPE-19 cell line is a widely used cell line for eye study, while TNF- $\alpha$ is a pro-inflammatory cytokine that induces inflammation in ARPE-19 cells [52]. Treatment with AKE prevented TNF- $\alpha$-inducible inflammation in ARPE-19 cells with attenuation of TNF- $\alpha$, IL- $1 \beta$, IL-6, IL-8, and MMP-9 mRNA expression (Figure 4A). In addition, post-translational modification by phosphorylation of mitogen-activated protein kinase (MAPK) was examined, which is a key pathway signal transduction in inflammation. Phosphorylation of p-38 and p-ERK proteins was markedly attenuated in AKE-treated ARPE-19 cells (Figure 4B, Figure S1). By contrast, retinopathy is closely related to increased ocular ER stress activated in the retina and retinal endothelial cells under diabetic and hypoxic conditions [53,54].

Given the potent anti-inflammatory properties of AKE, we asked whether AKE would be effective in preventing other ocular stresses, such as oxidative stress or ER stress. To address this question, we induced ER stress in ARPE-19 cells by treatment with $\mathrm{Tg}(5 \mu \mathrm{mol} / \mathrm{L})$ in the presence or absence of AKE. VEGF- $\alpha$ has been identified as a proangiogenic factor involved in the pathophysiology of some ocular diseases with neovascularization [55]. The level of VEGF- $\alpha$ is a general marker of eye disease. At a $10 \mu \mathrm{g} / \mathrm{mL}$ dose, AKE significantly decreased Tg-inducible VEGF- $\alpha$ secretion into the media (Figure 4C). Loss of cellular homeostasis and disruption of $\mathrm{Ca}^{2+}$ signaling can lead to the activation of ER stress responses in both the reticular network and cytoplasmic compartments [56]. Tg treatment has remarkably increased $\left[\mathrm{Ca}^{2+}\right]_{\mathrm{i}}$ in ARPE-19 cells, implying that ER stress has also increased. AKE treatment decreased $\left[\mathrm{Ca}^{2+}\right]_{i}$ release from ARPE-19 cells compared with the Tg group, suggesting that AKE may prevent Tg-induced ocular ER stress in ARPE-19 cells (Figure 4D). Taken together, AKE can attenuate inflammatory responses and Tg-inducible ER stress in human retinal epithelial cells.
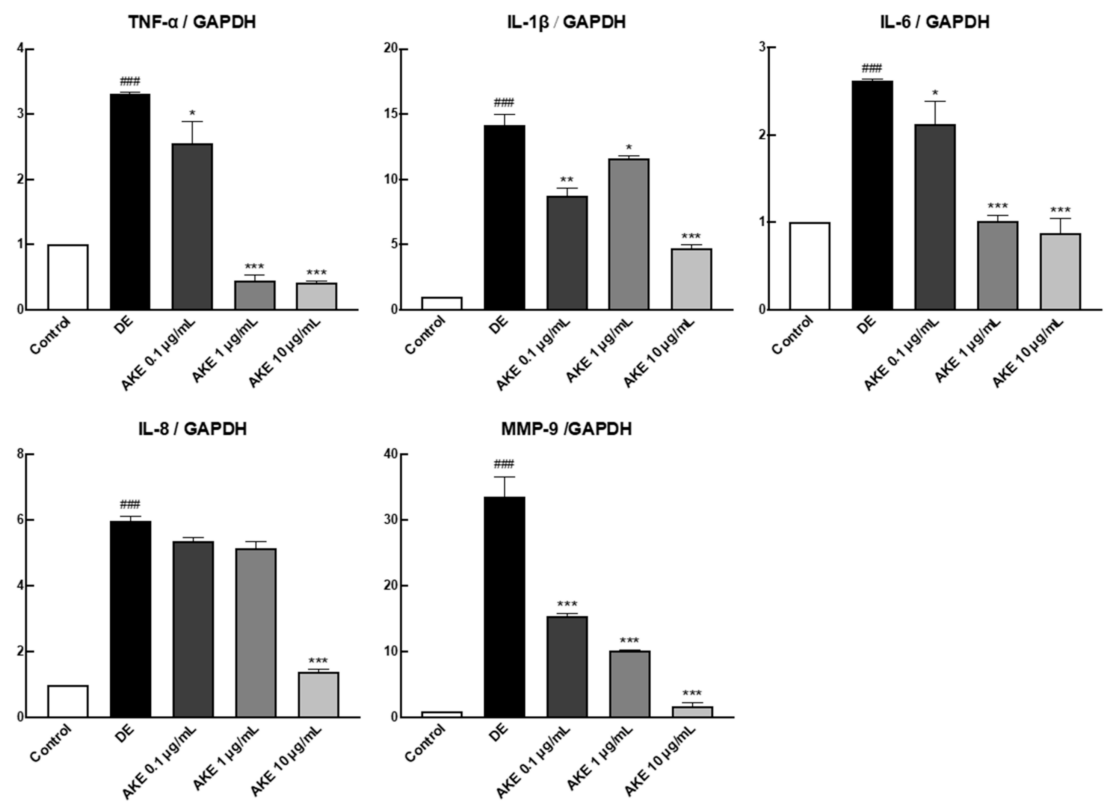

(A)

Figure 4. Cont. 


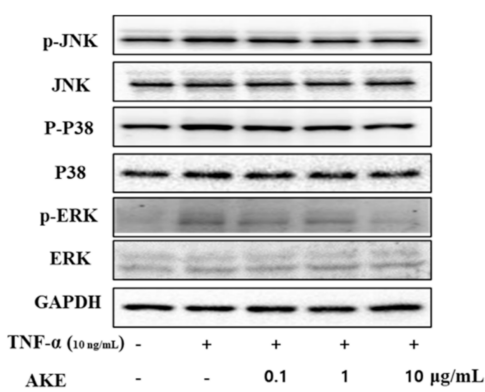

(B)

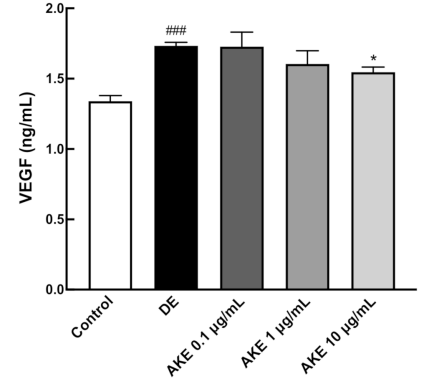

(C)

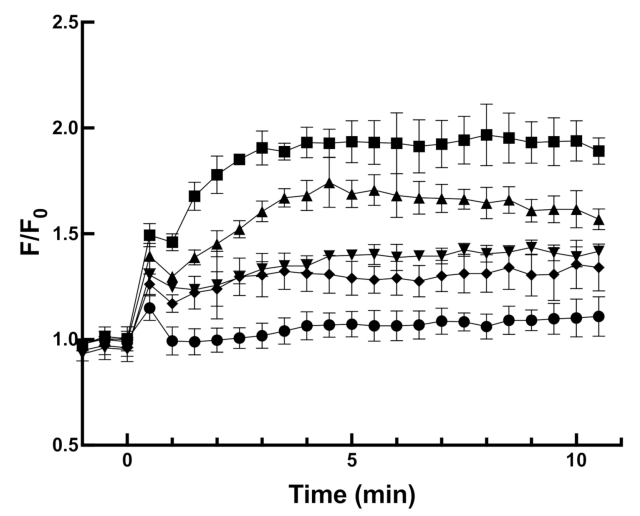

- Control

- Negative contro

- AKE $0.1 \mu \mathrm{g} / \mathrm{mL}$

マ AKE $1 \mu \mathrm{g} / \mathrm{mL}$

- AKE $10 \mu \mathrm{g} / \mathrm{mL}$

(D)

Figure 4. Effects of A. koraiensis ethanol extracts (AKE) on ER stress and the inflammatory response in animal model and human retinal pigmented epithelial (ARPE-19) cells. TNF- $\alpha$-inducible pro-inflammatory gene expression in AKE-treated ARPE-19 cells. To induce an inflammatory reaction, phosphate buffered saline (PBS) or $10 \mu \mathrm{g} / \mathrm{mL}$ of TNF- $\alpha$ was treated, and AKE was treated in a dose-dependent manner (0, 0.1, 1, and $10 \mathrm{mg} / \mathrm{mL}$ ). (A) Inflammatory cytokines were measured by qRT-PCR in order to validate the expression of each target gene (TNF-a, IL-1b, IL-6, IL-8, and MMP-9). glyceraldehyde 3-phosphate dehydrogenase (GAPDH) was used as an internal control. (B) The intracellular inflammatory signaling (MAPK) was analyzed using western blot (WB) with specific antibodies such as phospho-c-Jun N-terminal kinase (p-JNK), JNK, p-P38, P38, phospho-extracellular signal regulated kinase (p-ERK), and ERK. GAPDH was used for loading control. (C and D) endoplasmic reticulum (ER) stress was induced in ARPE-19 cells by thapsigargin (Tg), and AKE was treated with 0 (control; CON), $0.1 \mu \mathrm{g} / \mathrm{mL}$ (AKE 0.1), $1 \mu \mathrm{g} / \mathrm{mL}$ treatment (AKE 1), and $10 \mu \mathrm{g} / \mathrm{mL}$ treatment (AKE 10). (C) Tg-induced VEGF- $\alpha$ expression was measured using ELISA. (D) Tg-induced calcium ion efflux measurement using fluorescence. Data from three independent experiments have been presented as bar graphs showing mean $\pm \mathrm{SD}$. ${ }^{\# \# \#} p<0.001$ versus $\mathrm{CON}^{*} p<0.05,{ }^{* *} p<0.01,{ }^{* * *} p<0.001$ versus DE. Data were analyzed statistically using one-way ANOVA, followed by Tukey's test. For $\left[\mathrm{Ca}^{2+}\right]_{\mathrm{i}}$ determination, two-way ANOVA with repeated measures was used, followed by Tukey's hoc test. A, TC, D) Negative control to DE.

\section{Discussion}

Dry eye syndrome (DES) has been defined as a chronic eye disease associated with aging, hormonal changes, inflammation, and autoimmune diseases [57]. The eyes of a patient with DE contain upregulation of inflammatory cytokines, such as IL- 8 , IL-6, IL-1 $\beta$, TGF- $\beta$, and TNF- $\alpha$, and infiltration of immune cells [58]. Therefore, the inhibition of an inflammatory reaction is one of the clinical strategies in treating DE [59]. Multiple inflammation-suppressive therapeutic agents, including cyclosporine A (immunosuppressive agent), corticosteroids (steroid), and tetracycline (anti-inflammatory drug), have been widely used in clinical practice to treat patients with DES. However, these agents only partly attenuate clinical symptoms; not all agents relieve the complete burden of DE symptoms. Thus, 
natural sources have been considered that produce fewer adverse side effects and promote easy usage of agents [60,61], and would be an alternative material for the treatment of DE symptoms.

A. koraiensis has been traditionally used as a treatment for diabetes and inflammatory-related diseases in Korea. A previous study has reported that A. koraiensis plays a vital role in retinal angiogenesis and oxidative stress-inducible retinopathy [33]. Inflammation-induced by ocular surface stress can lead to an immune response in order to generate additional damage and amplify inflammation [62]. In this study, we investigated whether AKE reduces ocular inflammation and ER stress. Our results demonstrated that oral administration of AKE to DE mice reversed the symptoms as it increased TBUT and improved tear production from lacrimal glands. Moreover, AKE treatment modestly augmented histological remodeling in the corneal epithelium and lacrimal glands from DE mice to a level similar to that of the control group. Atrophy of the lacrimal gland and loss of acinar cells leads to an osmotic imbalance in the tear film and propels the infiltration of inflammatory cells and expression of inflammatory cytokines, such as IL-1 $\beta$, TNF- $\alpha$, IFN- $\gamma$, and MMP-9, on the ocular surface and lacrimal glands [63-65]. The activation of NF- $\mathrm{BB}$ signaling was reported to stimulate inflammatory chemokines and cytokines, including IL-1 $\beta$, IL- 6 , TNF- $\alpha, C-X-C$ motif chemokine 5 (CXCL5), C-X-C motif chemokine 8 (CXCL8), and monocyte chemoattractant protein 1 (MCP1) [66,67]. Additionally, IL-1 $\beta$ also activates COX-1 and COX-2, which are responsible for the synthesis of prostaglandins and contribute to the regulation of the inflammatory response [68].

Treatment with AKE $(50 \mathrm{mg} / \mathrm{kg})$ has restored tear production and acinar cells in the lacrimal gland of mice with experimental DE. Moreover, AKE significantly inhibited ocular inflammation in these mice through the downregulation of inflammatory mediators such as IL- $1 \beta$, TNF- $\alpha$, IFN- $\gamma$, and TGF- $\beta$ at the transcriptional level in corneal tissue and lacrimal glands. It also suppressed the phosphorylation of i nhibitory $\kappa \mathrm{Ba}(\mathrm{I} \kappa \mathrm{Ba})$ at a translational level. However, other inflammatory proteins, NF- $\mathrm{k} B, \mathrm{COX}-1$, and COX-2, did not alter dramatically, although AKE was effective in mitigating scopolamine-inducible DE in vivo. These findings suggest that AKE partially suppresses ocular inflammation and may affect other ocular stresses, such as oxidative and ER stress. Among the functional fractions of AKE, chlorogenic acids (CGAs) and 3,5-O-dicaffeoylquinic acids were identified to possess anti-inflammatory effects $[69,70]$. The anti-inflammatory response of AKE may rely on these functional chemicals. However, additional studies with specific functional components from the fractionated AKE should be performed to elucidate the active components of AKE.

Chronic ocular inflammation in DE also causes retinal damage. In a TNF- $\alpha$-induced retinal inflammation (RI) model, AKE attenuated IL-1 $\beta$, TNF- $\alpha$, IL-6, IL-8, and MMP-9 in a dose-dependent manner. Along with NF- $\mathrm{KB}$, the MAPK pathway plays a crucial role in inflammation, infiltration of innate immune cells, antigen presentation, and upregulation of inflammatory molecules [71,72]. Activation of the MAPK pathway was markedly attenuated in AKE-treated ARPE-19 cells. Together, these data suggest that AKE may reduce local inflammation in ocular tissues by suppressing the activation of inflammatory cytokines and the MAPK pathway. RI has been determined as a prominent signature in the pathogenesis of age-related macular degeneration, DR, and uveitis [73]. The anti-inflammatory effects of AKE need further investigation to reduce the burden of RI as well as DE.

ER stress is another primary intracellular event with chronic local inflammation [74]. In DR and retinal degeneration, increased ocular neovascularization and apoptosis were observed along with elevation of ER stress [75,76]. In the present study, AKE treatment was also determined to affect the inhibition of ER stress-related cellular pathologies. Additionally, we demonstrated that AKE has sufficient potency to inhibit the expression of VEGF- $\alpha$ and increase $\left[\mathrm{Ca}^{2+}\right]_{\mathrm{i}}$ levels in a model stress-triggered system. Previously, it was reported that VEGF- $\alpha$ and corneal lymphangiogenesis are increased in the DE mouse model [77]. Type 2 diabetes mellitus often triggers patients to have ophthalmic complications, including corneal abnormalities, glaucoma, iris neovascularization, cataracts, and neuropathies [78]. DR is the most common medical complication of these ophthalmic complications as it damages the blood vessels in the retina [79]. Indeed, DR is associated with increased intraocular 
levels of VEGF- $\alpha$ [78]. However, Shin et al. [80] reported that general nutrients and antioxidant bioactive materials such as polyphenolic substances in A. koraiensis possessed radical scavenging activity and reducing power. The current report promotes the study of the antioxidant ability by $\mathrm{AKE}$ as one of the underlying mechanisms to inhibit DE. As summarized in Tables 3 and 4, a high concentration of AKE was associated with greater antioxidative activities. A study investigating the protective effects of muscadine grape polyphenols (MGPs) demonstrated that the major polyphenols (quercetin, ellagic acid, myricetin, and kaempferol) in MGPs effectively attenuated ocular inflammation and ER stress [81]. In the present study, we demonstrated that AKE mitigated symptoms of DE, including corneal epithelium thinning, lacrimal gland tissue gap formation, and tear production decline. The underlying mechanism is that AKE treatment inhibited inflammatory responses to attenuate the activation of IKB. Moreover, AKE treatment ameliorated retinal inflammation and ER stress.

\section{Conclusions}

In conclusion, the oral administration of AKE could be an effective treatment for DES or inflammation caused by ocular disorders. Especially, substances derived from natural products are in the limelight as raw materials for functional foods in that they can be easily processed as raw materials for food, and their safety is generally guaranteed. Therefore, if it is used as a functional material that anyone can easily accept and as a material for health foods for improving eye health, it can be judged that it is beneficial for reducing inflammation and alleviating DE. However, before it can be used as an actual food ingredient, evaluating its health effects in a human test, such as repetition and genetic toxicity, is required. If we do more of these studies, we can expect that they can be used as a convenient natural resource to improve DES.

Supplementary Materials: The following are available online at http://www.mdpi.com/2072-6643/12/11/3245/s1, Figure S1: The Inflammatory signaling (MAPK) were analyzed by western blot (WB) for supplementary data Figure 4B.

Author Contributions: Conceptualization, S.H.J. and J.-C.K.; Methodology, S.-C.H. and J.-C.K.; Software S.-C.H.; Validation, S.-C.H. and J.-C.K.; Formal Analysis, S.-C.H.; Investigation, S.-C.H. and J.-C.K.; Resources S.H.J. and J.-C.K.; Data Curation, S.-C.H. and J.-H.H.; Writing-Original Draft Preparation, S.-C.H., J.-H.H. and J.-C.K.; Writing-Review and Editing, S.-C.H., J.-H.H., J.K.L. and J.-C.K.; Visualization, S.-C.H.; Supervision J.-C.K.; Project Administration, J.-C.K. and S.H.J.; Funding Acquisition J.-C.K. and J.S.H. All authors have read and agreed to the published version of the manuscript.

Funding: This research was financially supported by Korea Institute of Science and Technology (KIST) internal project (2Z05310) and the Ministry of Ocean and Fisheries in Korea (20190015).

Acknowledgments: This study is supported by Eye Health Food \& Drugs Exploration of Natural materials (2Z05310) from KIST, Korea, and in part by "Development of Advanced Process for the Production of Eye Health Materials Using Tetraselmis chuii", the Ministry of Ocean and Fisheries in Korea.

Conflicts of Interest: The authors confirm that article content has no conflict of interest.

\section{References}

1. Phadatare, S.P.; Momin, M.; Nighojkar, P.; Askarkar, S.; Singh, K.K. A comprehensive review on dry eye disease: Diagnosis, medical management, recent developments, and future challenges. Adv. Pharm. 2015, 2015, 704946. [CrossRef]

2. Paulsen, A.J.; Cruickshanks, K.J.; Fischer, M.E.; Huang, G.-H.; Klein, B.E.; Klein, R.; Dalton, D.S. Dry eye in the beaver dam offspring study: Prevalence, risk factors, and health-related quality of life. Am. J. Ophthalmol. 2014, 157, 799-806. [CrossRef] [PubMed]

3. Stahl, U.; Willcox, M.; Stapleton, F. Osmolality and tear film dynamics. Clin. Exp. Optom. 2012, 95, 3-11. [CrossRef] [PubMed]

4. Zhang, X.; Qu, Y.; He, X.; Ou, S.; Bu, J.; Jia, C.; Wang, J.; Wu, H.; Liu, Z.; Li, W. Dry eye management: Targeting the ocular surface microenvironment. Int. J. Mol. Sci. 2017, 18, 1398. [CrossRef]

5. Lee, L.; Garrett, Q.; Flanagan, J.; Chakrabarti, S.; Papas, E. Genetic factors and molecular mechanisms in dry eye disease. Ocul. Surf. 2018, 16, 206-217. [CrossRef] 
6. Liu, K.C.; Huynh, K.; Grubbs, J.; Davis, R.M. Autoimmunity in the pathogenesis and treatment of keratoconjunctivitis sicca. Curr. Allergy Asthma Rep. 2014, 14, 403. [CrossRef]

7. Baudouin, C.; Irkeç, M.; Messmer, E.M.; Benítez-del-Castillo, J.M.; Bonini, S.; Figueiredo, F.C.; Geerling, G.; Labetoulle, M.; Lemp, M.; Rolando, M. Clinical impact of inflammation in dry eye disease: Proceedings of the ODISSEY group meeting. Acta Ophthalmol. 2018, 96, 111-119. [CrossRef]

8. Chen, Y.; Zhang, X.; Yang, L.; Li, M.; Li, B.; Wang, W.; Sheng, M. Decreased PPAR- $\gamma$ expression in the conjunctiva and increased expression of TNF- $\alpha$ and IL-1 $\beta$ in the conjunctiva and tear fluid of dry eye mice. Mol. Med. Rep. 2014, 9, 2015-2023. [CrossRef]

9. VanDerMeid, K.R.; Su, S.P.; Ward, K.W.; Zhang, J.-Z. Correlation of tear inflammatory cytokines and matrix metalloproteinases with four dry eye diagnostic tests. Investig. Ophthalmol. Vis. Sci. 2012, 53, 1512-1518. [CrossRef]

10. Kunert, K.S.; Tisdale, A.S.; Stern, M.E.; Smith, J.; Gipson, I.K. Analysis of topical cyclosporine treatment of patients with dry eye syndrome: Effect on conjunctival lymphocytes. Arch. Ophthalmol. 2000, 118, 1489-1496. [CrossRef]

11. Rolando, M.; Stern, M.E.; Calonge, M. Modern perspectives on dry eye disease. Eur. Ophthalmic Rev. 2017, 11, 2-6.

12. Stern, M.E.; Schaumburg, C.S.; Pflugfelder, S.C. Dry eye as a mucosal autoimmune disease. Int. Rev. Immunol. 2013, 32, 19-41. [CrossRef]

13. Wei, Y.; Asbell, P.A. The core mechanism of dry eye disease (DED) is inflammation. Eye Contact Lens 2014, 40, 248. [CrossRef]

14. Xu, C.; Bailly-Maitre, B.; Reed, J.C. Endoplasmic reticulum stress: Cell life and death decisions. J. Clin. Investig. 2005, 115, 2656-2664. [CrossRef]

15. Bahar, E.; Kim, H.; Yoon, H. ER stress-mediated signaling: Action potential and $\mathrm{Ca}^{2+}$ as key players. Int. J. Mol. Sci. 2016, 17, 1558. [CrossRef] [PubMed]

16. Hotamisligil, G.S. Endoplasmic reticulum stress and the inflammatory basis of metabolic disease. Cell 2010, 140, 900-917. [CrossRef]

17. Seo, Y.; Ji, Y.; Lee, S.; Shim, J.; Noh, H.; Yeo, A.; Park, C.; Park, M.; Chang, E.; Lee, H. Activation of HIF-1 $\alpha$ (hypoxia inducible factor-1 $\alpha$ ) prevents dry eye-induced acinar cell death in the lacrimal gland. Cell Death Dis. 2014, 5, e1309. [CrossRef]

18. Barabino, S.; Chen, Y.; Chauhan, S.; Dana, R. Ocular surface immunity: Homeostatic mechanisms and their disruption in dry eye disease. Prog. Retin. Eye Res. 2012, 31, 271-285. [CrossRef]

19. Lin, H.; Yiu, S.C. Dry eye disease: A review of diagnostic approaches and treatments. Saudi J. Ophthalmol. 2014, 28, 173-181. [CrossRef] [PubMed]

20. Messmer, E.M. The pathophysiology, diagnosis, and treatment of dry eye disease. Dtsch. Ärztebl. Int. 2015, 112, 71. [CrossRef]

21. Downie, L.E.; Keller, P.R. A pragmatic approach to the management of dry eye disease: Evidence into practice. Optom. Vis. Sci. 2015, 92, 957-966. [CrossRef]

22. Sun, N.-N.; Wu, T.-Y.; Chau, C.-F. Natural dietary and herbal products in anti-obesity treatment. Molecules 2016, 21, 1351. [CrossRef]

23. Granato, D.; Barba, F.J.; Bursać Kovačević, D.; Lorenzo, J.M.; Cruz, A.G.; Putnik, P. Functional foods: Product development, technological trends, efficacy testing, and safety. Annu. Rev. Food Sci. Technol. 2020, 11, 93-118. [CrossRef]

24. Aguilar-Toalá, J.; Hernández-Mendoza, A.; González-Córdova, A.; Vallejo-Cordoba, B.; Liceaga, A. Potential role of natural bioactive peptides for development of cosmeceutical skin products. Peptides 2019, 122, 170170.

25. Hooshmand, S.; Arjmandi, B.H. Dried plum, an emerging functional food that may effectively improve bone health. Ageing Res. Rev. 2009, 8, 122-127. [CrossRef] [PubMed]

26. Park, S.-H.; Sim, Y.-B.; Kim, S.-M.; Kang, Y.-J.; Lee, J.-K.; Lim, S.-S.; Kim, J.-K.; Suh, H.-W. Antinociceptive profiles and mechanisms of orally administered Aster Koraiensis extract in the mouse. J. Med. Plants Res. 2011, 5, 6267-6272.

27. Ahn, D. Illustrated Book of Korean Medicinal Herbs; Kyohaksa: Seoul, Korea, 1998; Volume 497, pp. $23-115$.

28. Ko, J.; Lee, K. Effect of plant growth regulators on growth and flowering of potted Lychnis cognata, Aster koraiensis and Campanula takesimana. RDA J. Agric. Sci. Korea Repub. 1996, 38, 627-632. 
29. Lee, J.; Lee, Y.M.; Lee, B.W.; Kim, J.-H.; Kim, J.S. Chemical constituents from the aerial parts of Aster koraiensis with protein glycation and aldose reductase inhibitory activities. J. Nat. Prod. 2012, 75, 267-270. [CrossRef]

30. Sohn, E.; Kim, J.; Kim, C.-S.; Kim, Y.S.; Jang, D.S.; Kim, J.S. Extract of the aerial parts of Aster koraiensis reduced development of diabetic nephropathy via anti-apoptosis of podocytes in streptozotocin-induced diabetic rats. Biochem. Biophys. Res. Commun. 2010, 391, 733-738. [CrossRef]

31. Hyun, S.-W.; Kim, J.; Jo, K.; Kim, J.S.; Kim, C.-S. Aster koraiensis extract improves impaired skin wound healing during hyperglycemia. Integr. Med. Res. 2018, 7, 351-357. [CrossRef] [PubMed]

32. Kim, J.; Jo, K.; Lee, I.-S.; Kim, C.-S.; Kim, J.S. The extract of Aster Koraiensis prevents retinal Pericyte apoptosis in diabetic rats and its active compound, chlorogenic acid inhibits AGE formation and AGE/RAGE interaction. Nutrients 2016, 8, 585. [CrossRef] [PubMed]

33. Kim, J.; Lee, Y.M.; Jung, W.; Park, S.-B.; Kim, C.-S.; Kim, J.S. Aster koraiensis extract and chlorogenic acid inhibit retinal angiogenesis in a mouse model of oxygen-induced retinopathy. Evid. Based Complementary Altern. Med. 2018, 2018, 4916497. [CrossRef] [PubMed]

34. Serpen, A.; Gökmen, V.; Fogliano, V. Total antioxidant capacities of raw and cooked meats. Meat Sci. 2012, 90, 60-65. [CrossRef]

35. Thaipong, K.; Boonprakob, U.; Crosby, K.; Cisneros-Zevallos, L.; Byrne, D.H. Comparison of ABTS, DPPH, FRAP, and ORAC assays for estimating antioxidant activity from guava fruit extracts. J. Food Compos. Anal. 2006, 19, 669-675. [CrossRef]

36. Benzie, I.F.; Strain, J. [2] Ferric reducing/antioxidant power assay: Direct measure of total antioxidant activity of biological fluids and modified version for simultaneous measurement of total antioxidant power and ascorbic acid concentration. In Methods in Enzymology; Academic Press: Cambridge, MA, USA, 1999; Volume 299, pp. 15-27.

37. Oki, T.; Nagai, S.; Yoshinaga, M.; Nishiba, Y.; Suda, I. Contribution of $\beta$-carotene to radical scavenging capacity varies among orange-fleshed sweet potato cultivars. Food Sci. Technol. Res. 2006, 12, 156-160. [CrossRef]

38. Re, R.; Pellegrini, N.; Proteggente, A.; Pannala, A.; Yang, M.; Rice-Evans, C. Antioxidant activity applying an improved ABTS radical cation decolorization assay. Free Radic. Biol. Med. 1999, 26, 1231-1237. [CrossRef]

39. Alves, R.C.; Costa, A.S.; Jerez, M.; Casal, S.; Sineiro, J.; Nunez, M.J.; Oliveira, B. Antiradical activity, phenolics profile, and hydroxymethylfurfural in espresso coffee: Influence of technological factors. J. Agric. Food Chem. 2010, 58, 12221-12229. [CrossRef] [PubMed]

40. Pourmorad, F.; Hosseinimehr, S.; Shahabimajd, N. Antioxidant activity, phenol and flavonoid contents of some selected Iranian medicinal plants. Afr. J. Biotechnol. 2006, 5, 1142-1145.

41. Marinova, D.; Ribarova, F.; Atanassova, M. Total phenolics and total flavonoids in Bulgarian fruits and vegetables. J. Univ. Chem. Technol. Metallurgy 2005, 40, 255-260.

42. Kasote, D.M.; Katyare, S.S.; Hegde, M.V.; Bae, H. Significance of antioxidant potential of plants and its relevance to therapeutic applications. Int. J. Biol. Sci. 2015, 11, 982. [CrossRef]

43. El Jemli, M.; Kamal, R.; Marmouzi, I.; Zerrouki, A.; Cherrah, Y.; Alaoui, K. Radical-scavenging activity and ferric reducing ability of Juniperus thurifera (L.), J. oxycedrus (L.), J. phoenicea (L.) and Tetraclinis articulata (L.). Adv. Pharmacol. Sci. 2016, 2016, 6392656.

44. Javadi, M.-A.; Feizi, S. Dry eye syndrome. J. Ophthalmic Vis. Res. 2011, 6, 192.

45. Dienes, L.; Kiss, H.J.; Perényi, K.; Nagy, Z.Z.; Acosta, M.C.; Gallar, J.; Kovács, I. Corneal sensitivity and dry eye symptoms in patients with keratoconus. PLoS ONE 2015, 10, e0141621. [CrossRef] [PubMed]

46. Conrady, C.D.; Joos, Z.P.; Patel, B.C. The lacrimal gland and its role in dry eye. J. Ophthalmol. 2016, 2016, 7542929. [CrossRef]

47. Tiwari, S.; Ali, M.J.; Vemuganti, G.K. Human lacrimal gland regeneration: Perspectives and review of literature. Saudi J. Ophthalmol. 2014, 28, 12-18. [CrossRef] [PubMed]

48. Khwaja, A. Akt is more than just a Bad kinase. Nature 1999, 401, 33-34. [CrossRef] [PubMed]

49. Viatour, P.; Merville, M.P.; Bours, V.; Chariot, A. Phosphorylation of NF-kappaB and IkappaB proteins: Implications in cancer and inflammation. Trends Biochem. Sci. 2005, 30, 43-52. [CrossRef] [PubMed]

50. Sánchez-Chávez, G.; Hernández-Ramírez, E.; Osorio-Paz, I.; Hernández-Espinosa, C.; Salceda, R. Potential role of endoplasmic reticulum stress in pathogenesis of diabetic retinopathy. Neurochem. Res. 2016, 41, 1098-1106. [CrossRef] 
51. Bose, T.; Diedrichs-Möhring, M.; Wildner, G. Dry eye disease and uveitis: A closer look at immune mechanisms in animal models of two ocular autoimmune diseases. Autoimmun. Rev. 2016, 15, 1181-1192. [CrossRef]

52. An, E.; Gordish-Dressman, H.; Hathout, Y. Effect of TNF- $\alpha$ on human ARPE-19-secreted proteins. Mol. Vis. 2008, 14, 2292.

53. Salminen, A.; Kauppinen, A.; Hyttinen, J.M.; Toropainen, E.; Kaarniranta, K. Endoplasmic reticulum stress in age-related macular degeneration: Trigger for neovascularization. Mol. Med. 2010, 16, 535-542. [CrossRef] [PubMed]

54. Li, J.; Wang, J.J.; Yu, Q.; Wang, M.; Zhang, S.X. Endoplasmic reticulum stress is implicated in retinal inflammation and diabetic retinopathy. FEBS Lett. 2009, 583, 1521-1527. [CrossRef]

55. Krzystolik, M.G.; Afshari, M.A.; Adamis, A.P.; Gaudreault, J.; Gragoudas, E.S.; Michaud, N.A.; Li, W.; Connolly, E.; O'Neill, C.A.; Miller, J.W. Prevention of experimental choroidal neovascularization with intravitreal anti-vascular endothelial growth factor antibody fragment. Arch. Ophthalmol. 2002, 120, 338-346. [CrossRef]

56. Krebs, J.; Agellon, L.B.; Michalak, M. $\mathrm{Ca}^{2+}$ homeostasis and endoplasmic reticulum (ER) stress: An integrated view of calcium signaling. Biochem. Biophys. Res. Commun. 2015, 460, 114-121. [CrossRef]

57. Pflugfelder, S.C.; de Paiva, C.S. The pathophysiology of dry eye disease: What we know and future directions for research. Ophthalmology 2017, 124, S4-S13. [CrossRef] [PubMed]

58. Clayton, J.A. Dry eye. N. Engl. J. Med. 2018, 378, 2212-2223. [CrossRef]

59. Kang, W.S.; Jung, E.; Kim, J. Aucuba japonica extract and aucubin prevent desiccating stress-induced corneal epithelial cell injury and improve tear secretion in a mouse model of dry eye disease. Molecules 2018, 23, 2599. [CrossRef] [PubMed]

60. Martin, E.; Oliver, K.M.; Pearce, E.I.; Tomlinson, A.; Simmons, P.; Hagan, S. Effect of tear supplements on signs, symptoms and inflammatory markers in dry eye. Cytokine 2018, 105, 37-44. [CrossRef]

61. Devec1, H.; Kobak, S. The efficacy of topical $0.05 \%$ cyclosporine A in patients with dry eye disease associated with Sjögren's syndrome. Int. Ophthalmol. 2014, 34, 1043-1048. [CrossRef]

62. McMonnies, C.W. Conjunctival tear layer temperature, evaporation, hyperosmolarity, inflammation, hyperemia, tissue damage, and symptoms: A review of an amplifying cascade. Curr. Eye Res. 2017, 42, 1574-1584. [CrossRef]

63. Guzmán, M.; Keitelman, I.; Sabbione, F.; Trevani, A.S.; Giordano, M.N.; Galletti, J.G. Mucosal tolerance disruption favors disease progression in an extraorbital lacrimal gland excision model of murine dry eye. Exp. Eye Res. 2016, 151, 19-22. [CrossRef] [PubMed]

64. De Paiva, C.S.; Corrales, R.M.; Villarreal, A.L.; Farley, W.J.; Li, D.-Q.; Stern, M.E.; Pflugfelder, S.C. Corticosteroid and doxycycline suppress MMP-9 and inflammatory cytokine expression, MAPK activation in the corneal epithelium in experimental dry eye. Exp. Eye Res. 2006, 83, 526-535. [CrossRef] [PubMed]

65. Aragona, P.; Aguennouz, M.H.; Rania, L.; Postorino, E.; Sommario, M.S.; Roszkowska, A.M.; De Pasquale, M.G.; Pisani, A.; Puzzolo, D. Matrix metalloproteinase 9 and transglutaminase 2 expression at the ocular surface in patients with different forms of dry eye disease. Ophthalmology 2015, 122, 62-71. [CrossRef] [PubMed]

66. Liu, T.; Zhang, L.; Joo, D.; Sun, S.-C. NF-кB signaling in inflammation. Signal Transduct. Target. Ther. 2017, 2, 1-9. [CrossRef]

67. Tornatore, L.; Thotakura, A.K.; Bennett, J.; Moretti, M.; Franzoso, G. The nuclear factor kappa B signaling pathway: Integrating metabolism with inflammation. Trends Cell Biol. 2012, 22, 557-566. [CrossRef]

68. Ricciotti, E.; FitzGerald, G.A. Prostaglandins and inflammation. Arterioscler. Thromb. Vasc. Biol. 2011, 31, 986-1000. [CrossRef]

69. Liang, N.; Kitts, D.D. Role of chlorogenic acids in controlling oxidative and inflammatory stress conditions. Nutrients 2016, 8, 16. [CrossRef]

70. Abdel Motaal, A.; Ezzat, S.M.; Tadros, M.G.; El-Askary, H.I. In vivo anti-inflammatory activity of caffeoylquinic acid derivatives from Solidago virgaurea in rats. Pharm. Biol. 2016, 54, 2864-2870. [CrossRef]

71. Newton, K.; Dixit, V.M. Signaling in innate immunity and inflammation. Cold Spring Harb. Perspect. Biol. 2012, 4, a006049. [CrossRef]

72. Kyriakis, J.M.; Avruch, J. Mammalian MAPK signal transduction pathways activated by stress and inflammation: A 10-year update. Physiol. Rev. 2012, 2, 807-869. [CrossRef]

73. Whitcup, S.M.; Nussenblatt, R.B.; Lightman, S.L.; Hollander, D.A. Inflammation in retinal disease. Int. J. Inflamm. 2013, 2013, 724648. [CrossRef] [PubMed] 
74. Sprenkle, N.T.; Sims, S.G.; Sánchez, C.L.; Meares, G.P. Endoplasmic reticulum stress and inflammation in the central nervous system. Mol. Neurodegener. 2017, 12,1-18. [CrossRef] [PubMed]

75. Kroeger, H.; Chiang, W.C.; Felden, J.; Nguyen, A.; Lin, J.H. ER stress and unfolded protein response in ocular health and disease. FEBS J. 2019, 286, 399-412. [CrossRef]

76. Zhang, S.X.; Sanders, E.; Fliesler, S.J.; Wang, J.J. Endoplasmic reticulum stress and the unfolded protein responses in retinal degeneration. Exp. Eye Res. 2014, 125, 30-40. [CrossRef] [PubMed]

77. Goyal,S.; Chauhan, S.K.; El Annan, J.; Nallasamy, N.; Zhang, Q.; Dana, R. Evidence of corneal lymphangiogenesis in dry eye disease: A potential link to adaptive immunity? Arch. Ophthalmol. 2010, 128, 819-824. [CrossRef]

78. Titchenell, P.M.; Antonetti, D.A. Using the past to inform the future: Anti-VEGF therapy as a road map to develop novel therapies for diabetic retinopathy. Diabetes 2013, 62, 1808-1815. [CrossRef] [PubMed]

79. Stolar, M. Glycemic control and complications in type 2 diabetes mellitus. Am. J. Med. 2010, 123, S3-S11. [CrossRef]

80. Shin, E.H.; Park, S.J. Component analysis and antioxidant activity of Aster koraiensis Nakai. J. Korean Soc. Food Sci. Nutr. 2014, 43, 74-79. [CrossRef]

81. Ha, J.-H.; Shil, P.K.; Zhu, P.; Gu, L.; Li, Q.; Chung, S. Ocular inflammation and endoplasmic reticulum stress are attenuated by supplementation with grape polyphenols in human retinal pigmented epithelium cells and in C57BL/6 mice. J. Nutr. 2014, 144, 799-806. [CrossRef]

Publisher's Note: MDPI stays neutral with regard to jurisdictional claims in published maps and institutional affiliations.

(C) 2020 by the authors. Licensee MDPI, Basel, Switzerland. This article is an open access article distributed under the terms and conditions of the Creative Commons Attribution (CC BY) license (http://creativecommons.org/licenses/by/4.0/). 